Vol. 2 No 2, Agustus 2020

ISSN 2657-0203

e-ISSN 2686-0244

\title{
WORKSHOP PEGIAT MEDSOS SEBAGAI AKTUALISASI CITIZEN JOURNALISM UNTUK PEWARTAAN GEREJA DI KEUSKUPAN MALANG
}

Engelbertus Kukuh Widijatmoko ${ }^{1}$, Ludovikus Bomans Wadu ${ }^{2}$, Andri Fransiskus Gultom ${ }^{3}$

kukuhwidijatmoko@unikama.ac.id, ludovikusbomanwadu@unikama.ac.id, andri.franz@unikama.ac.id

\begin{abstract}
ABSTRAK
Dalam Pendidikan Kewarganegaraan tidak hanya berfokus kepada pengetahuan semata. Melalui pendidikan kewarganegaraan diharapkan dapat mengembangkan kompetensi kewarganegaraan seperti pengetahuan, keterampilan dan watak/karakter. Untuk memperkuat kompetensi kewarganegaraan dalam konteks keterampilan warga negara salah satu cara yang dapat dilakukan adalah dengan Citizenship Journalism. Oleh karena itu pengabdian ini akan memfokuskan pada keterampilan warga negara dalam konsep Citizenship Journalisme untuk mendukung kompetensi kewarganegaraan pegiat media sosial di paroki dalam wilayah Keuskupan Malang. Adapun luaran pada kegiatan pengabdian ini adalah database pengelola media sosial yang diikuti 31 paroki di Keuskupan Malang dan laporan pengabdian masyarakat.
\end{abstract}

\section{PENDAHULUAN}

Citizen Journalism atau yang dikenal juga dengan jurnalisme warga merupakan sebuah proses produksi informasi atau peristiwa yang ada disekitar kehidupan sehari hari yang dilakukan oleh warga negara melalui berbagai media. (Eddyono et al., 2019) Media yang dimaksudkan tidak hanya media resmi dari kantor berita atau media masa, tetapi juga bisa dilakukan melalui berbagai media sosial yang dimiliki oleh warga negara. Selain itu jurnalisme warga bisa kitakan sebagai berita yang dikirimkan oleh warga biasa tanpa memiliki latarbelakang jurnalisme, ini juga dikenal dengan civic journalism yang merupakan sebuah perlawanan terhadap media public yang muncul 
Vol. 2 No 2, Agustus 2020

ISSN 2657-0203

e-ISSN 2686-0244

karena ketidakpercayaan public terhadap politik di negara Amerika Serikat (Kurniawan, 2007). Disaat ini jurnalisme warga dapat dilakukan oleh berbagai kalangan untuk menyampaikan informasi terkait peristiwa yang ada disekitarnya ataupun menginformasikan kegiatan yang sedang dilakukan oleh organisasi, sekolah atau berbagai lembaga lainnya yang sifatnya sebagai media informasi tentang kegiatan kegiatan yang telah ataupun yang akan dilakukan oleh mereka.

Jurnalisme warga juga harus diimbangi dengan pertimbangan moral yang baik oleh penyampai informasi agar informasi yang diberikan tidak melanggar berbagai kode etik atau yang dikenal dengan Undang-Undang Tentang Informasi Dan Transaksi Elektronik (Undang-Undang Republik Indonesia Nomor 19 Tahun 2016 Tentang Perubahan Atas Undang-Undang Nomor 11 Tahun 2008 Tentang Informasi Dan Transaksi Elektronik). Oleh karena itu dibutuhkan Pendidikan nilai moral untuk mengimbangi hal tersebut.

Pendidikan Nilai Moral adalah suatu usaha sadar yang dilakukan oleh pendidik yang terencana dalam memberikan atau menanamkan nilai-nilai estetik dan etik tentang baik buruk, benar dan salah mengenai suatu perbuatan atau sikap agar bertanggung jawab (Nawawi, 2010). Nilai moral merupakan keyakinan yang dipegang oleh seseorang tentang mana yang dianggap salah dan mana yang dianggap benar dalam perilaku manusia, dan perbedaan antara keduanya (Abdullah et al., 2010). Moral merupakan kondisi pikiran, perasaan, ucapan, dan perilaku manusia yang memiliki nilai-nilai baik dan buruk dalam berinteraksi dengan lingkungan sekitar (Sutika, 2017). Pendidikan Kewarganegaraan merupakan pendidikan nilai - nilai moral yang sangat diperlukan dalam berkehidupan sebagai warga Negara dan warga masyarakat yang merupakan suatu kehidupan berbangsa dan bernegara (Wahyuningsih \& Purwanti, 2016)

Pendidikan adalah upaya yang ditempuh oleh manusia untuk mengubah perilaku sehingga menjadi peribadi yang lebih baik serta mampu mengembangkan pengetahuan yang dimiliki (Khaironi, 2017). Salah satu strategi pendidikan dilakukanlah workshop. Worshop ini khusus bagi pegiatan media sosial di paroki 
Vol. 2 No 2, Agustus 2020

ISSN 2657-0203

e-ISSN 2686-0244

dalam wilayah Keuskupan Malang. Hal itu sebagaimana dinyatakan dalam UndangUndang Sisdiknas Nomor 20 Tahun 2003, di jelaskan bahwa:

Pendidikan adalah usaha sadar dan terencana untuk mewujudkan suasana belajar dan proses pembelajaran agar peserta didik secara aktif mengembangkan potensi dirinya untuk memiliki kekuatan spiritual keagamaan, pengendalian diri, kepribadian, kecerdasan, akhlak mulia, serta keterampilan yang diperlukan dirinya, masyarakat, bangsa dan Negara.

Merujuk pada tujuan akhir pendidikan kewarganegaraan (PKn) adalah menjadikan warga Negara yang baik dan juga cerdas. Untuk mencapai tujuan tersebut dibutuhkan kompetensi kewarganegaraan. Kompetensi kewarganegaraan mencakup 3 hal yakni pengetahuan, keterampilan dan watak/karakter.Gambaran kondisi saat ini, masih banyak pelajaran PKn di sekolah yang hanya memfokuskan pada pengetahuan semata.Sedangkan keterampilan dan watak/karakter masih belum ditercapai.

Secara Khusus pengabdian ini akan membantu Bidang pewartaan melalui media sosial masih sebatas meneruskan pesan-pesan, Perlu kreatifitas bagi Admin WAG di Paroki dan Belum adanya koordinasi antar admin WAG antar paroki. Selain itu secara umum pengabdian ini membantu terwujudnya tujuan PKn dalam kompetensi kewarganegaran bidang pewartaan di paroki dalam wilayah Keuskupan Malang.

\section{METODE}

Berdasarkan uraian permasalahan yang telah diuraikan sebelumnya maka solusi yang dapat diberikan adalah melaksanakan pengabdian dengan menggunakan metode workshop yang didalamnya diselingi diskusi, tanya jawab dan merancang program selanjutnya. Workshop yang dilakukan ini menargetkan pada para pengelola /admin WAG Paroki Keuskupan Malang yang dilaksanakan selama 3 hari yang dilakukan dalam 7 sesi dengan mengundang narasumber dalam memberikan perluasan perspektif peran penting pengelola/admin WAG paroki. 
Vol. 2 No 2, Agustus 2020

ISSN 2657-0203

e-ISSN 2686-0244

Partisipasi mitra dalam hal ini adalah pengelola/admin WAG paroki keuskupan Malang. Beberapa cara untuk mendorong mitra agar memberikan partisipasi aktif dalam melaksanakan program pengabdi an ini antara lain:(1) Adanya sosialisasi terlebih dahulu sebelum dilaksanakan kegiatan workshop pediat media sosial paroki di wilayah Keuskupan Malang. (2) Adanya kegiatan pendampingan yang akan mengisi konten kreatif fresh berspiritualitas Kristiani. (3) Mengikutsertakan mitra Romo Paroki / Ketua Bidang Pewartaan dalam kepanitiaan kegiatan terutama dalam penyebaran informasi kepada peserta sehingga mitra lebih memahami tujuan kegiatan ini serta semangat dalam mengikuti kegiatan.

\section{HASIL DAN PEMBAHASAN}

Secara umum hasil pengabdian yang didapatkan selama 3 hari pelaksanaan workshop ini terlihat peserta sangat antusias. Ini dibuktikan dengan semangat yang mereka tunjukan dalam mengikuti berbagai materi yang dibahas dan diskusikan selama workshop. Kegiatan workshop ini kemudian munculkan beberapa hal penting yang berkaitan dengan kesadaran akan pentingnya jurnalisme warga negara dalam hal berbagi informasi kegiatan antar paroki.

Selain itu ditemukan hasil secara khusus sebagai berikut. Pertama, dibutuhkan wadah untuk komunikasi bagi pegiat media sosial antar-paroki. Wadah ini digunakan untuk mempublikasikan berbagai kegiatan secara bersama sama dalam sebuah website. Website ini menampung aneka liputan dengan fitur berdasar Panca tugas Gereja yaitu Bidang Liturgi, Bidang Pewartaan, Bidang Pelayanan, Bidang Paguyuban dan Bidang Kesaksian.

Kedua, dibutuhkan distribusi berbagi liputan kegiatan antar-paroki. Melalui website bersama ini diharapkan dapat menjadi sebuah wadah bersama bagi penayangan liputan-liputan kegiatan antar-paroki di wilayah Keuskupan Malang. Website bersama ini memungkinkan berbagai warga paroki untuk bisa mengetahui, membaca dan mengikuti perkembangan kegiatan paroki-paroki lainnya. Website bersama bisa menjadi inspirasi kegiatan paroki lain di wilayah Keuskupan Malang. 
Vol. 2 No 2, Agustus 2020

ISSN 2657-0203

e-ISSN 2686-0244

Ketiga, dibutuhkan peningkatan intensitas komunikasi pegiat media sosial. Komunikasi dimaksudnya untuk saling mengevaluasi liputan. Para pegiatan diberi kesempatan memberikan kritik, saran dan penilaian atas tayangan liputan antar-paroki di wilayah Keuskuapan Malang. Hal ini diupayakan agar konten liputan terus mengalami kemajuan sesuai dengan perkembangan penulisan di media sosial.

Keempat, dibutuhkan upgrading pegiat media sosial tingkat keuskupan. Upgrading meliputi metode penulisan, aspek hukum, dan konten website. Hal ini diperlukan agar para pegiatan terus berupaya melakukan inovasi konten website dan sekaligus kesadaran hukum dalam dunia media sosial. Aspek hukum perlu disosialisasikan agar rambu-rambu hukum terlebih UU ITE dipahami dan dipatuhi sebelum penayangan di website.

\section{SIMPULAN}

Beberapa kesimpulan yang diperoleh dari Workshop Pegiat Medsos Sebagai Aktualisasi Citizen Journalism Untuk Pewartaan Gereja antara lain: (1) Kegiatan pengabdian kepada masyarakat berupa Workshop Pegiat Medsos Untuk Pewartaan Paroki Keuskupan Malang terbagi kedalam 9 sesi kegiatan. (2) Melalui kegiatan Workshop Pegiat Medsos Sebagai Aktualisasi Citizen Journalism Untuk Pewartaan Paroki Keuskupan Malang pegiat media sosoal paroki mendapat suntikan tim, inspirasi dan ide kratif. (3) Kegiatan Workshop Pegiat Medsos Sebagai Aktualisasi Citizen Journalism Untuk Pewartaan Paroki Keuskupan Malang pengelola media sosial terbetuk jejarin informasi dan sharing info kegitan dari berbagai paroki di keuskupan Malang. (4) Kegiatan Workshop Pegiat Medsos Sebagai Aktualisasi Citizen Journalism Untuk Pewartaan Paroki Keuskupan Malang menambah kapasitas intelektual, perspektif, sosial dan jejaring untuk berusaha menghadirkan informasi berdasar karya terang Roh Kudus.

\section{DAFTAR PUSTAKA}

Abdullah, S., Salleh, A., Mahmud, Z., \& Ghani, S. A. (2010). Moral value inventory for Muslim Adolescents. Procedia - Social and Behavioral Sciences, 7(C), 106- 
112. https://doi.org/10.1016/j.sbspro.2010.10.016

Eddyono, A. S., HT, F., \& Irawanto, B. (2019). Menyoroti Jurnalisme Warga:

Lintasan Sejarah, Konflik Kepentingan, dan Keterkaitannya dengan Jurnalisme Profesional. Jurnal Kajian Jurnalisme, 3(1), 1. https://doi.org/10.24198/jkj.v3i1.21762

Khaironi. (2017). Pendidikan Moral Pada Anak Usia Dini. Jurnal Golden Age Universitas Hamzanwadi, 1, 1-16.

Kurniawan, M. N. (2007). Jurnalisme Warga Di Indonesia, Prospek Dan Tantangannya. Makara Human Behavior Studies in Asia, 11(2), 71. https://doi.org/10.7454/mssh.v11i2.115

Nawawi. (2010). Pentingnya Pendidikan Nilai Moral Bagi Generasi Penerus. Universitas Pendidikan Indonesia.

Sutika, I. M. (2017). Implementasi Pendidikan Keluarga Dalam Menanamkan NilaiNilai Moral Anak ( Studi Di Taman Penitipan Anak Werdhi Kumara I Panjer Kecamatan Denpasar Selatan). Jurnal Kajian Pendidikan Widya Accarya FKIP Universitas Dwijendra, 1-10. https://doi.org/10.1108/02640470810893738

Undang-Undang Republik Indonesia Nomor 19 Tahun 2016 Tentang Perubahan Atas Undang-Undang Nomor 11 Tahun 2008 Tentang Informasi Dan Transaksi Elektronik.

Undang-Undang No 20 Tahun 2003.Sistem Pendidikan Nasional. Jakarta: Depdiknas Wahyuningsih, L., \& Purwanti, R. S. (2016). Implementasi Pendidikan Moral Terhadap Mata Pelajaran Pendidikan Kewarganegaraan Kelas Rendah di SD Sutran Sabdodadi Bantul. 1-10. 